\title{
The Impact of Educational Games-Based iPad Applications on the Development of Social Studies Achievement and Learning Retention among Sixth Grade Students in Jeddah
}

\author{
Hanan A. Najmuldeen ${ }^{1, *}$ \\ ${ }^{1}$ Curricula and Instruction of Social Studies, Faculty of Education, University of Jeddah, KSA \\ *Correspondence: Curricula and Instruction of Social Studies, Faculty of Education, University of Jeddah, KSA. \\ E-mail: hnajmaldeen@uj.edu.sa
}

Received: April 23, 2017

Accepted: May 11, 2017 Online Published: June 6, 2017

doi:10.5430/wje.v7n3p21

URL: https://doi.org/10.5430/wje.v7n3p21

\begin{abstract}
The present study aims to evaluate the impact of educational games-based iPad applications on the development of social studies achievement and learning retention. Sample consisted of (48) sixth grade primary students in Jeddah. The author adopted Quasi-experimental design of the experimental and control groups. She also provided the teacher a guidebook that explains teaching method using educational games-based iPad applications. Pre-post achievement test was applied to both groups. Delayed achievement test, which evaluates learning retention, was applied four weeks after post-test. The study showed the impact of educational games-based iPad applications on achievement and learning retention with statistically significant differences in scores means of both groups' participants in posttest and delayed test in favor of the experimental group. She recommended using iPad educational applications, which she prepared, in teaching.
\end{abstract}

Keywords: iPad educational applications; learning retention; educational games; social studies achievement

\section{Introduction}

Early in the new millennium, various developments have appeared in learning process; radical modifications have occurred in some curricula, their content and teaching method. Accordingly, interest in using technology and means of communication increased. Thus, learning process was enriched with modern materials, devices and methods which saved time and made education better and more effective.

When the young had used electronic games, such as PlayStation, Xbox, Gameboy, and Wii at the age of three, their life related to the games from which they learn and gain most behaviors. It also affects their characters. Accordingly, playing involves cognitive aspects related to the child's comprehension and thinking (Al Shahroura \& Al Remawy, 2011). The introduction of Tablets, such as Galaxy Tab, IPad and IPod and smart phones, such as IPhone, BlackBerry and Galaxy created a revolution in the world of technology and communication. IPad, which is small, light and fabulous and easily connects to the internet, came out in 2010 . Consequently, the individual could carry his small computer anywhere. Then, all companies, which commenced producing smart Tablets, competed Apple company. Its demand increased because most people started to use it. As a result, games various applications have become prevalent, attracted the young, adolescents and adults' attention and occupied their minds. This topic created an argument between two teams of educators; the first is optimistic and the other is pessimistic about children's use of these games which is a double-edged weapon. Dipietro et al (2007) report that these games affect the culture of community as various types of E-games appeared in many disciplines for various purposes, including education, especially after being downloadable applications from stores of programs, applications and games.

Al Nafeai (2009), in Aleqtisadiah Newspaper, stated that Saudi child spends 400 USD on E-games per year. Cesarone et al (2000) indicated that $90 \%$ of fourth grade students play E-games for an hour at least per week and males excel females. Actually, these games affect both processes of teaching and learning cognitive processes. Thus, teacher and student could use educational applications on smart tablets. They comprise learning and playing. Comparing to the price of educational programs, which are installed on computers, some are free, and others are less costly. Otsuki et al (2004) assured that playing provides children the environment which plays a role in their 
development and motivates them to learn and interact with the facts and concepts that are close to their perception. Hense et al (2012) stated that learning process, which occurs through playing and entertainment, is based on three aspects: Learning Theory, Tendencies Theory, and Motivation Theory. Studies of Psychology and Education proved that learning games, which activate intelligence, keep the pupil in the educational institution and increase his learning motivation. Previously, Educators, such as Froebel who established houses where children learn through games and Montessori who called for the significance of paying attention to games and led to the prevalence of Montessori games, focused on using games-based learning strategy in learning and education field

Various studies, such as Al Harby (2010), recommended using E-learning games as a method of learning and instructing, and Zahran and Ahmed (2010) and Elawn(2012) recommended using games in teaching through their inclusion in learning process.

Studies, such as Al Harby (2010) and Alsaidi (2014) which handled the impact of E-learning games, proved the effectiveness of E-learning games in learning retention. IPad learning applications increased games. Accordingly, it is essential to use these games in learning and compromise them with its objectives. The author saw that she had to conduct a study to verify the impact of educational games-based iPad applications on achievement and learning retention.

\subsection{Statement of the Problem}

Problem of the present study is involved in the reality of using games applications. The author noticed that individuals of different ages are keen on using games available on smart devices. Gros (2007) assured that researchers and educators have recently paid E-learning games much attention. However, it's little comparing to the industry which produces hundred thousand games.

Games are used according to the concept of turning harm into benefit and negative into positive. Education should meet the students' needs and tendencies. Introducing games greatly affects teaching children a lot of experience and knowledge because they enhance learning. Petsche (2011) claims that iPad educational games can make a change in learning process because several applications that enhance learning courses, such as mathematics, geography, science and history, came out. They make learning stunning and create opportunities for the application of knowledge in a virtual world, so learning process will be facilitated and enhanced (Anonymous, 2010) . Moreover, they are familiar with students of different ages because of the rapid prevalence of mobile devices and the development of their options (Demirbilek, 2010).

Eduactional games aims to find an educational room which incorporates achievemnt with entertianment to creates excitemnt and motivation. Thus, they improve achievemnt (Otsuki et al., 2004). They create competition among a students and groups, so they will be motivated. Also, Fester (2012) reports that applications of cell phone and tablets will greatly affect the community and will be used in teaching and learning in five years. IPad will be substantially used. Ray and Coulter (2010) concluded that games effectively enhance learning social studies. Al ران (2010) and Al Saidi (2014) illustrated that educational games have an impact on learning retention. Accoringly, probem of the study is defined in the following question:

What is the impact of educational games-based IPad applications on the achievement of social studies and learning retention among sixth grade primary students in Jeddah

\subsection{Objectives of the Study}

The present study attempts to identify the following aspects:

1. The impact of educational games-based IPad applications on the development of social studies achievement among students.

2. The impact of educational games-based IPad applications on learning retention of social studies among students.

\subsection{Definition of Terms}

IPad educational applications are a part of games despite their different names. The author defines educational games according to the concept that the applications are a type of games or incorporated into them.

\subsection{Procedural Definition}

Educational games, which the author designed using Ipad applications that are specialized for designing attractive games and activities in specific templates, permits adding cognitive content, images and maps related to each lesson in (Resources of my Country) unit. They are played while explaining the lesson using IPad. The study comprises three applications as follows: 


\section{- TINY TAP}

- Quiz Maker

- Puzzle Maker

\subsection{Academic Achievement}

It stands for the concepts and knowledge of (Resources of my Country) unit, which the sixth primary grade students gain. It's evaluated according to the student's score in post-achievement test after each unit.

\subsection{Learning Retention}

According to Ellaqanyand Al Gamal (2013), it is the outcome of learning retained in the memory and is evaluated according to the student's score in the post- test, no less than two months after the pre-test

\subsection{Procedural Definition}

It is the outcome of what's retained from the achievement (knowledge and concepts) of (Resources of my Country) unit and it's evaluated according to the student's score in the delayed achievement test which is conducted four weeks after post-test.

\subsection{Theoretical Background}

Recently, Computer games have rapidly developed. In addition, the production of non-educational games, which focus on virtual world, has increased. Consequently, researchers and educators paid educational games much attention. As soon as IPad educational applications, which are played through touch technique, had come out, the third generation of all various games appeared. Playing benefits students and positively affects intellectual and emotional development. It also enables them to solve their problems in an appropriate environment, which pays attention to their entertainment and tendencies. Learning involves three patterns as follows:

1. Audio (listening-based learning)

2. Visual (watching- based learning)

3. Touch/motor (Physical practice-based learning) (Petsche, 2011).

\subsection{Essential Elements of Educational Games}

According to the Arab Academy of E-learning (2010), educational games, either traditional or electronic, comprise essential elements and basics, as follows:

1. Objective: They must have an obvious specific objective compatible with the player's goal.

2. Rules: Each game should have its own rules.

3. Competition: Achieving goals is based on competition between a player and another, a player and the game, a player and criterion, to master a skill or achieve specific goals.

4. Challenge: Game involves appropriate challenge that reasonably stimulates the individual's capabilities.

5. Imagination: Game stimulates the individual's imagination in order to motivate him to learn.

6. Entertainment: Game provides entertainment, which is mainly based on, but it should be equivalent to learning content.

In addition to the above-mentioned elements which both the traditional and electronic games share, educational games should incorporate the following elements:

1. Adaptation: Game should consider students' different learning types, and difference of their previous information, prospects and goals.

2. Stimulants and Positive Response: Learning, provided by the game, is a stimulant and necessitates an instant response in order to move to another step.

3. Feedback and Instant Enhancement: When learner responds to the stimulant, game shows him an instant result which enhances and motivates him to go on playing.

\subsection{Advantages of iPad Educational Applications}

iPad applications and educational games share various advantages which the author concluded because of using such applications:

- They are easily downloaded and installed in Apple store. 
- They are less costly than other educational programs.

- They provide the instructions that help the user.

- They provide learner instant enhancement so that it can increase his interaction with the educational situation.

- IOS operating system is fast and doesn't contain viruses.

- Based on touch feature, they are easily played.

- They decrease verbal aspect in learning.

- They take into account individual differences.

- They motivate learner.

- They match the learner's tendencies and meet his needs.

- Despite of their benefits and advantages, such devices are double-edged weapon because their overuse affects learners' health and behaviors negatively.

\subsection{Types of iPad Educational Applications}

Apple store involve several applications of educational games. Some are free, others are paid. However, they aren't as costly as the other educational programs. They involve two types:

1. Ready-made applications of educational games that are used in teaching numbers and letters, such as:

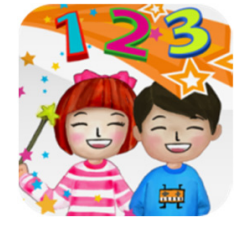

123 fun Application

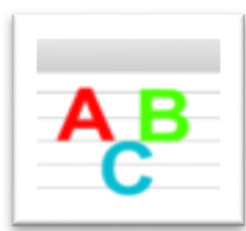

ABC's Writer Application

2. Applications that permit designing educational games through adding content, image, sounds and motion, such as:

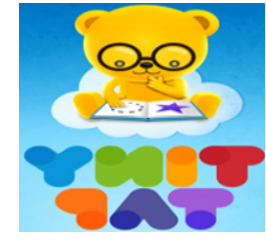

TINY TAP Application

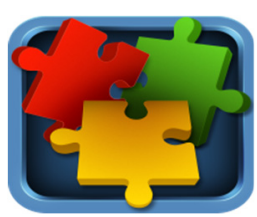

Puzzle Games Application

The author will adopt the above-mentioned applications in addition to quiz marker application to make interactive questions assigned for final and constructive assessment of the unit.

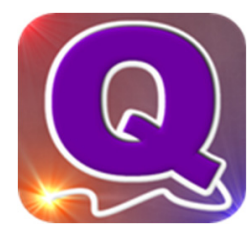

Quiz marker application

\subsection{Standards of Using Educational Games-based IPad Applications}

On preparing educational games, various standards should be taken into account so that such games will achieve their educational objectives. The author has adopted such standards which Attia (2008) mentioned as effective programming standards in order to be compatible with educational games-based IPad applications. Such standards are as follows:

1. They should be designed according to the objectives that the learner will achieve after learning. 
2. They should involve instructions and guidelines that show playing method, especially if the games is based on self-learning.

3. They provide learner more opportunities of participation and positive interaction.

4. They involve attraction and entertainment.

5. They are easily used so that learner won't feel disappointed.

6. They involve feedback and enhancement.

7. They should consider principles and basics of learning.

8. They should involve all aspects of interaction, such as: audio, video, images and illustrations.

\section{Literature Review}

Schuck et al. (2016) aimed to improve scholastic behavior of the children who suffer from hyperactivity and attention deficit. Self-control application, which focuses on the student's discipline, productivity, and positive relations at the same time, was used. A sample consisting of 12 fifth grade students, using IPad individually, was taught for 13 days. Results showed there is a difference between students' scores and teachers' scores. Variance test between students' scores and teachers' scores showed that there are differences between teachers' evaluation and students' evaluation because students might tend to positively evaluate their behavior; they provide themselves the highest scores. According to Falloon and Khoo(2014), researchers in Waikato University used applications devoted to display data and sound to five-year-old students. They aimed to teach arithmetic, eradicate illiteracy and solve problems. Results showed advanced levels in the achievement of tasks. IPad, a device of common general learning, was used to help the students learn basic rules that appropriately improve speech quality.

Flower (2014) claims that time on-task is critical in the classroom because it is linked to learning and success. Many students with disabilities struggle with remaining on-task, particularly during independent practice periods. Strategies to increase time on-task during classroom activities are sorely needed, particularly for independent practice. An alternating treatments design was used to investigate the effect of an iPad on time on-task during independent practice for three students with emotional/behavioral disorders compared to their time on-task during a typical independent practice condition. Additionally, teachers' and students' viewpoints regarding effectiveness of the iPad and acceptability of its use were assessed. Findings suggested that iPad use produced increased time on-task compared to the typical independent practice condition for all three students. Teachers and students perceived the iPad as a positive addition as they both viewed it as effective and acceptable.

Carr (2012) aimed to identify the effectiveness of learning games-based tablets applications on 5th-grade students' mathematics achievement. Sample consisted of (104) students, divided into experimental and control groups, in two rural Virginia elementary schools. Quasi-experimental approach was used to investigate the effects of iPad. Wireless Internet access was provided to create exciting interactive learning opportunities for students. Change wasn't significantly different between the two groups.

Demirbilek (2010) aimed to investigate adult educators' attitudes and perceptions of the use of mobile devices' digital educational games in education. Sample consisted of (113) educators in 8 European counties. Results showed that $76 \%$ of adult educators expressed their interest to use mobile devices in their learning activities, half of participants (50\%) preferred synchronous games and 33\% of subjects think that open source games would be better learning games due to the ongoing possibilities for future modification and development. Adult educators indicated a willingness to employ electronic games on mobile devices.

\section{Hypotheses of the Study}

1. There are statistically significant differences at significance level $(\alpha \geq 0.05)$ between scores means of both groups' ( experimental and control) students in the post-achievement test of ( Resources of my Country) unit which is assigned for sixth grade primary students after pre-control.

2. There are statistically significant differences at significance level $(\alpha \geq 0.05)$ between scores means of both groups' (experimental and control) students in the delayed achievement test of (Resources of my Country) unit which is assigned for sixth grade primary students after pre-control. 


\section{Procedures of the Study}

\subsection{Methodology}

The author used experimental approach based on quasi-experimental design of the experimental and control groups (Al Noah, 2006). The impact of independent variable on dependent variables was tested. Pre-test was applied to the participants of both groups (achievement test).

Then, students of the experimental group studied the sixth unit in social studies course which was taught to $6^{\text {th }}$ primary grade according to educational games-based iPad applications. Whereas, control group traditionally studied the same unit. Post-test (achievement test) was applied to both groups. Six weeks later, achievement test was applied again to estimate learning retention. The author used quasi-experimental design ( it doesn't involve random division of groups and control of external variables) because she applied her study to a school to which she was directed by Women Education Administration, Jeddah.

\subsection{Population}

All students (161) of the primary school in Jeddah.

\subsection{Sampling}

Two classes (Sixth A and Sixth B) in the above-mentioned school were selected. A class (Sixth A) was selected as an experimental sample; the other (Sixth B) was selected as a control sample for the following reasons:

- Classes, whose courses times are appropriate for the author, were selected.

- Number of students in each group is appropriate for the implementation of the study.

Table 1. Number of Students in the Experimental and Control Groups

\begin{tabular}{llccc}
\hline Grade & Group & No. of Students & Absence & Total Number \\
\hline Sixth A & Experimental Group & 26 & 2 & 24 \\
Sixth B & Control Group & 25 & 1 & 24 \\
\multicolumn{1}{c}{ Total } & & 51 & 3 & 48 \\
\hline
\end{tabular}

\subsection{Tools of the Study}

To achieve the objectives, the author conducted the following procedures:

\section{A. Designing Educational Games using iPad Educational Applications}

\section{Steps}

A number of steps should be followed when designing educational games (Abdulrazeq, 2011). The author followed such steps which involve the following stages:

\section{Preparation Stage}

1. Task Analysis: It involves defining general objectives of iPad educational applications. It's the objective that each game attempts to achieve.

2. Learners' Analysis: The author had an interview with the participants of the experimental group (aged 11 and 12) to discern their ages and technical skills. She selected this stage to have a discussion with them and to make sure of their age appropriateness for the application of the experiment. $71 \% \mathrm{had} \mathrm{iPad,} 20 \% \mathrm{had}$ Galaxy Tap and 9\% didn't have tablet. Some students stated that iPad applications are user- friendly and all students know how to play them.

3. Content Analysis: The author acquainted with the course content of the sixth grade, and then she selected the sixth unit (Resources of my Country) because it's rich in information, numbers of its lessons are appropriate for the application of the experiment and images and media can be used to design games.

4. Defining Resources and Constraints: The author possesses four iPads; three are hers and one is her colleague's. During the interview, the author agreed with the students to follow their teacher's instructions; they use iPad at the request of the teacher. 


\section{Design Stage}

It involves the following steps:

- Defining procedural objectives: They are the behavioral objectives that can be evaluated. General objectives were converted into procedural ones in which educational games can be utilized and estimated.

- Defining program of creating and the usable device

Tablets programs are called application. The author selected the following applications.

- TINY TAP (for designing games)

- Puzzle Maker (for designing games)

- Quiz maker (To create final and constructive assessment of the unit)

3. Defining response patterns and feedback: Screen touch defined method of the students' response. Furthermore, pattern of feedback (the student hears and watches to check her answer. She also gets comments in some games) was defined.

4. Making preliminary chart of educational game design: It is everything that the student watches and interacts with while displaying the game. TINY TAP involves various backgrounds, that can be selected from templates in the application. Additionally, other images can be taken by the camera or downloaded from Google.

5. Constructive Assessment: It's conducted after explaining a section of the lesson. Quiz maker application, either free or paid, was used to create assessment questions.

\section{Stage of Production and Development}

The author handles creation program, which is selected to convert preliminary chart into educational games, according to the following steps:

1. Preparing the required multimedia: collecting and selecting the images and backgrounds, adopted in the game design, from Google images. They can also be derived from the curricula application. Media are inserted into iPad to facilitate production process.

2. Production of games in its preliminary frame: Creating them through the above-mentioned iPad applications, then they are sent to other devices via sharing option in TINY TAP application. While, Quiz maker doesn't have sharing option, so games and questions were created in one device which the teacher used through connecting it to data show.

3. Reviewing educational games: Having designed educational games in their preliminary frame, specialists and experienced teachers reviewed them and made adjustments (Appendix No. 2). Games were applied to a sample similar to the targeted one in another school to survey opinions and make the essential modifications.

4. Games in their final frame: They were played on the assigned tablets to make sure that they have no problems. Modifications were made when discovering any error. Accordingly, educational games got ready in their final frame.

5. Method of Application: Teacher of the class (Miss. Hoda Alzahrany) applied the experiment in the presence of the author who assisted her. Students of the experimental class were divided into four groups. Students were provided four iPads that would be used during the lesson (Appendix 1. involves detailed method) at the request of the teacher.

\section{B. Scholastic Achievement Test (Appendix No.3)}

The author prepared achievement test according to the following steps

- Test General Objective: Estimating the students' achievement of the sixth unit topics that was taught using educational games-based iPad applications.

- Detailed objectives: they involve behavioral objectives of each lesson. They are involved in the plan of the lesson in each topic (Appendix No. 1).

- Test Description: Test consists of cover page which involves instructions of the test, such as time, types and number of questions and number of pages.

- Questions of the Test: Test involves 20 questions: questions from 7 to 18 evaluate memorizing level, questions from 1 to 7 evaluate comprehension level and questions 19 and 20 evaluate application level. 
- Test Validity: Reviewers' Validity: Specialists in curricula and teaching methods and teachers experienced in teaching social studies course reviewed the test which was adjusted according to their instructions to have its final form (Appendix No. 2).

- Content Validity: Content validity is based on the situations that the test estimates (Bahi \& Al Namr, 2004). Accordingly, the author defined relative weight of the subject's significance according to the number of classes and objectives of the topic. Then, questions were created. Consequently, test handled the most significant concepts of each topic to involve all topics and comprehensively represent the content and objectives. The author found out content validity through the following table that tackles characteristics:

Table 2. Characteristics of the Sixth Unit's Achievement Test (Resources of My Country)

\begin{tabular}{|c|c|c|c|c|c|c|c|c|c|}
\hline \multirow{2}{*}{ Title } & \multirow{2}{*}{$\begin{array}{l}\text { No. of } \\
\text { Classes }\end{array}$} & \multicolumn{6}{|l|}{ Objectives } & \multirow{2}{*}{$\begin{array}{l}\text { Total No. of } \\
\text { Questions }\end{array}$} & \multirow{2}{*}{$\begin{array}{l}\text { Relative Weights o } \\
\text { Topics }\end{array}$} \\
\hline & & Memorizing & Comprehension & Application & Analysis & Creation & Assessment & & \\
\hline $\begin{array}{l}\text { Resources } \\
\text { of Water }\end{array}$ & 1 & 2 & 2 & - & - & - & - & 4 & $18 \%$ \\
\hline $\begin{array}{l}\text { Natural } \\
\text { Plant }\end{array}$ & 1 & 2 & 1 & - & - & - & - & 3 & $18 \%$ \\
\hline $\begin{array}{l}\text { Animal } \\
\text { Resources }\end{array}$ & 1 & 2 & 1 & - & - & - & - & 3 & $18 \%$ \\
\hline $\begin{array}{l}\text { Oil and } \\
\text { Minerals }\end{array}$ & 1 & 2 & 1 & 1 & - & - & - & 4 & $18 \%$ \\
\hline $\begin{array}{l}\text { Population } \\
\text { Activity }\end{array}$ & 2 & 3 & 2 & 1 & - & - & - & 6 & $28 \%$ \\
\hline Total & 6 & 10 & 7 & 2 & - & - & - & 20 & \multirow[b]{2}{*}{$100 \%$} \\
\hline \multicolumn{2}{|c|}{$\begin{array}{l}\text { Relative Weights of } \\
\text { Objectives }\end{array}$} & $52.5 \%$ & $38.3 \%$ & $9.2 \%$ & - & - & - & $100 \%$ & \\
\hline
\end{tabular}

Table (2) shows that the test handled all concepts of the topic; it represents the content and estimates what it has prepared.

Test Reliability: Coefficient of comprehension test reliability was estimated through the application of the test to a pilot sample consisting of 27 sixth grade students. Reliability coefficient was estimated using Cronbach's Alpha $(\alpha)$; value of test reliability coefficient was Reliability $\alpha=0.91$, it's a high value. Moreover, internal consistency coefficient of achievement test was estimated as follows:

Table 3. Internal Consistency of Achievement Test

\begin{tabular}{lc}
\hline Level & Correlation Coefficients \\
\hline $\begin{array}{l}\text { Knowledge } \\
\text { (memorizing) }\end{array}$ & 0.96 \\
Reasoning & \\
(comprehension) & 0.97 \\
Application & 0.94 \\
\hline
\end{tabular}

Table (3) shows that all correlation coefficients were at level $\geq 0,01$, i.e. there is high consistency among the lest levels.

- Checking the test: total mark is 20; one mark for the correct answer and zero for the wrong one.

- Defining Time: Test time of the pilot sample was observed. The first five minutes of the answer were estimated, other five minutes were added, then total time was divided on the number of students. Accordingly, time was approximately 30 minutes. 


\section{Variables of the Study}

- Independent Variable: ipad educational applications which were used to explain the sixth unit (Resources of my Country) lessons in the course of social studies assigned for the sixth grade students in the scholastics year 1437H./2016.

- Dependent Variables: Students' scores in: Achievement Test (before and after the experiment).

- Learning Retention (Application of Achievement Test after six weeks).

- Statistical Processing

The following statistical methods of (SPSS) were used:

- Alpha Cronbach to estimate tests reliability.

- One Way Analysis of Covariance (ANCOVA) to discipline the pre-impact between the experimental and control groups and detect the impact of educational games-based iPad applications on scholastic achievement and learning retention.

\section{Results and Discussion}

Green, et al. (1997) revealed that when there are statistically significant differences between groups of associated variable, ANCOVA is insignificant and provides untrue results. Thus, it was verified that there is no statistical significance, which (F) value shows, between both groups' achievement of associated variable (pre-application of each group) according to the following table:

Table 4. (F) Value in Scholastic Achievement Test

\begin{tabular}{|c|c|c|c|c|c|c|c|}
\hline Level & $\begin{array}{l}\text { Source } \\
\text { Variance }\end{array}$ & of & $\begin{array}{l}\text { Sum } \\
\text { of squares }\end{array}$ & $\begin{array}{l}\text { Freedom } \\
\text { Degree }\end{array}$ & $\begin{array}{l}\text { Mean of } \\
\text { Squares }\end{array}$ & $\mathrm{F}$ & Significance \\
\hline \multirow{2}{*}{$\begin{array}{l}\text { Knowledge } \\
\text { (memorizing) }\end{array}$} & $\begin{array}{l}\text { Between } \\
\text { Groups }\end{array}$ & & 0.32 & 1 & 0.32 & \multirow{2}{*}{0.254} & \multirow{2}{*}{0.61} \\
\hline & $\begin{array}{l}\text { Within } \\
\text { Groups }\end{array}$ & & 57.86 & 46 & 1.26 & & \\
\hline \multirow{2}{*}{$\begin{array}{l}\text { Reasoning } \\
\text { (comprehension) }\end{array}$} & $\begin{array}{l}\text { Between } \\
\text { Groups }\end{array}$ & & 0.79 & 1 & 0.79 & \multirow{2}{*}{0.512} & \multirow{2}{*}{0.46} \\
\hline & $\begin{array}{l}\text { Within } \\
\text { Groups }\end{array}$ & & 71.000 & 46 & 1.54 & & \\
\hline \multirow{2}{*}{ Application } & $\begin{array}{l}\text { Between } \\
\text { Groups }\end{array}$ & & 0.38 & 1 & 0.38 & \multirow[b]{2}{*}{0.61} & \multirow[b]{2}{*}{0.41} \\
\hline & $\begin{array}{l}\text { Within } \\
\text { Groups }\end{array}$ & & 20.96 & 46 & 0.46 & & \\
\hline \multirow{2}{*}{ Test } & $\begin{array}{l}\text { Between } \\
\text { Groups }\end{array}$ & & 1.02 & 1 & 1.02 & \multirow{2}{*}{0.232} & \multirow{2}{*}{0.63} \\
\hline & $\begin{array}{l}\text { Within } \\
\text { Groups }\end{array}$ & & 202.46 & 46 & 4.401 & & \\
\hline
\end{tabular}

Table (4) indicates that (F) value has no statistical significance for all levels of the achievement test

\subsection{Test of Hypotheses Validity}

1. There are statistically significant differences at significance level $(\alpha \geq 0.05)$ between scores means of both groups' (experimental and control) students in the post-achievement test of (Resources of my Country) unit which is assigned for sixth grade primary students after pre-control.

(F) value was estimated using (ANCOVA) of significance of differences between scores means of the experimental and control groups in the post-application of achievement test levels (memorizing, comprehension and application) through control of both groups' pre-achievement. Table (5) shows results of adjusted means and standard error of both groups' post-test scores. 
Table 5. Results of Adjusted Means and Standard Error of Both Groups' Post-Test Scores at the Levels of (Memorizing, Comprehension and Application)

\begin{tabular}{lllll}
\hline Level & Group & No. & $\begin{array}{l}\text { Adjusted } \\
\text { Post-Means }\end{array}$ & $\begin{array}{l}\text { Standard } \\
\text { Error }\end{array}$ \\
\hline Knowledge (memorizing) & Experimental & 24 & $4.83 \mathrm{a}$ & .1730 \\
& Control & 24 & $2.38 \mathrm{a}$ & .1730 \\
& Experimental & 24 & $6.07 \mathrm{a}$ & .1830 \\
Reasoning & Control & 24 & $2.27 \mathrm{a}$ & .1830 \\
(comprehension) & Experimental & 24 & $3.52 \mathrm{a}$ & .1400 \\
& Control & 24 & $1.53 \mathrm{a}$ & .1400 \\
Application & Experimental & 24 & $14.38 \mathrm{a}$ & .3720 \\
& Control & 24 & $6.04 \mathrm{a}$ & .3720 \\
Test & & & &
\end{tabular}

Table (6) shows (ANOVA) results of significance of differences among adjusted means of both groups' post-test scores.

Table 6. (ANOVA) Results of Significance of Differences among Adjusted Means of Both Groups' Post-Test Scores at the Levels of (Memorizing, Comprehension and Application)

\begin{tabular}{|c|c|c|c|c|c|c|c|}
\hline Level & $\begin{array}{l}\text { Source of } \\
\text { Variance }\end{array}$ & $\begin{array}{l}\text { Sum } \\
\text { of squares }\end{array}$ & $\begin{array}{l}\text { Freedom } \\
\text { Degree }\end{array}$ & $\begin{array}{l}\text { Mean of } \\
\text { Squares }\end{array}$ & $\begin{array}{l}(\mathrm{F}) \\
\text { Value }\end{array}$ & $\begin{array}{l}\text { Statistical } \\
\text { Significance }\end{array}$ & $\begin{array}{l}\text { Eta } \\
\text { Square }\end{array}$ \\
\hline \multirow{2}{*}{$\begin{array}{l}\text { Knowledge } \\
\text { ( memorizing) }\end{array}$} & $\begin{array}{l}\text { Between } \\
\text { Groups }\end{array}$ & 56.22 & 1 & 56.22 & \multirow{2}{*}{44.01} & \multirow{2}{*}{0010.} & \multirow[b]{2}{*}{0.49} \\
\hline & $\begin{array}{l}\text { Within } \\
\text { Groups }\end{array}$ & 57.48 & 46 & 1.28 & & & \\
\hline \multirow{2}{*}{$\begin{array}{l}\text { Reasoning } \\
\text { ( comprehension) }\end{array}$} & $\begin{array}{l}\text { Between } \\
\text { Groups }\end{array}$ & 144.33 & 1 & 104,372 & \multirow{2}{*}{54.24} & \multirow{2}{*}{0010.} & \multirow[b]{2}{*}{0.55} \\
\hline & $\begin{array}{l}\text { Within } \\
\text { Groups }\end{array}$ & 119.74 & 46 & 2.66 & & & \\
\hline \multirow[b]{2}{*}{ Application } & $\begin{array}{l}\text { Between } \\
\text { Groups }\end{array}$ & 42.499 & 1 & 42.499 & \multirow{2}{*}{42.32} & \multirow{2}{*}{0010.} & \multirow[b]{2}{*}{0.48} \\
\hline & $\begin{array}{l}\text { Within } \\
\text { Groups }\end{array}$ & 45.194 & 46 & 1.004 & & & \\
\hline \multirow[b]{2}{*}{ Test } & $\begin{array}{l}\text { Between } \\
\text { Groups }\end{array}$ & 831.37 & 1 & 831.37 & \multirow{2}{*}{74.54} & \multirow{2}{*}{0010.} & \multirow[b]{2}{*}{0.62} \\
\hline & $\begin{array}{l}\text { Within } \\
\text { Groups }\end{array}$ & 501.92 & 46 & 11.15 & & & \\
\hline
\end{tabular}

Table (6) shows that there are statistically significant of differences between both groups' post-test means at the levels of (memorizing, comprehension and application), in favor of the experimental group at significance level ( $\alpha$ $\geq 0.05)$

\subsection{Validity Test of the Second Hypothesis}

II. There are statistically significant differences at significance level $(\alpha \geq 0.05)$ between scores means of both groups' (experimental and control) students in the delayed achievement test of (Resources of my Country) unit which is assigned for sixth grade primary students after pre-control.

(F) value was estimated using (ANCOVA) of significance of differences between scores means of the experimental and control groups in the delayed application of achievement test levels (memorizing, comprehension and application) through control of both groups' pre-achievement.

Table (7) shows results of adjusted means and standard deviation of both groups' delayed achievement test scores at 
the levels of (memorizing, comprehension and application).

Table 7. Results of Adjusted Means and Standard Deviation of Both Groups' Delayed Achievement Test Scores at the Levels of (Memorizing, Comprehension and Application)

\begin{tabular}{lllll}
\hline Level & Source of Variance & Number & $\begin{array}{l}\text { Adjusted } \\
\text { Pots-Means }\end{array}$ & $\begin{array}{l}\text { Standard } \\
\text { Error }\end{array}$ \\
\hline $\begin{array}{l}\text { Knowledge } \\
\text { (memorizing) }\end{array}$ & Between Groups & 24 & $4.16 \mathrm{a}$ & .320 \\
& Within Groups & 24 & $3.03 \mathrm{a}$ & .320 \\
& Between Groups & 24 & $5.82 \mathrm{a}$ & .2960 \\
Reasoning & Within Groups & 24 & $4.23 \mathrm{a}$ & .2960 \\
(comprehension) & Between Groups & 24 & $5.54 \mathrm{a}$ & .1090 \\
& Within Groups & 24 & $3.01 \mathrm{a}$ & .1090 \\
Application & Between Groups & 24 & $15.16 \mathrm{a}$ & 0.49 \\
& Within Groups & 24 & $10.59 \mathrm{a}$ & .490 \\
\hline
\end{tabular}

Table (7) shows (ANOVA) results of significance of differences among adjusted means of both groups' delayed test scores.

Table 8. (ANOVA) Results of Significance of Differences among Adjusted Means of Both Groups' Delayed Achievement Test at the Levels of (Memorizing, Comprehension and Application)

\begin{tabular}{|c|c|c|c|c|c|c|c|}
\hline Level & $\begin{array}{l}\text { Source of } \\
\text { Variance }\end{array}$ & $\begin{array}{l}\text { Sum } \\
\text { of squares }\end{array}$ & $\begin{array}{l}\text { Freedom } \\
\text { Degree }\end{array}$ & $\begin{array}{l}\text { Mean of } \\
\text { Squares }\end{array}$ & $\begin{array}{l}(\mathrm{F}) \\
\text { Value }\end{array}$ & $\begin{array}{l}\text { Statistical } \\
\text { Significance }\end{array}$ & $\begin{array}{l}\text { Eta } \\
\text { Square }\end{array}$ \\
\hline \multirow{2}{*}{$\begin{array}{l}\text { Knowledge } \\
\text { (memorizing) }\end{array}$} & $\begin{array}{l}\text { Between } \\
\text { Groups }\end{array}$ & 12.60 & 1 & 12.60 & \multirow[t]{2}{*}{5.86} & \multirow[t]{2}{*}{.020} & \multirow[t]{2}{*}{0.11} \\
\hline & $\begin{array}{l}\text { Within } \\
\text { Groups }\end{array}$ & 96.77 & 46 & 2.15 & & & \\
\hline \multirow{2}{*}{$\begin{array}{l}\text { Reasoning } \\
\text { (comprehension) }\end{array}$} & $\begin{array}{l}\text { Between } \\
\text { Groups }\end{array}$ & 25.29 & 1 & 25.29 & \multirow{2}{*}{13.18} & \multirow{2}{*}{.001} & \multirow{2}{*}{0.23} \\
\hline & $\begin{array}{l}\text { Within } \\
\text { Groups }\end{array}$ & 86.18 & 46 & 1.92 & & & \\
\hline \multirow[b]{2}{*}{ Application } & $\begin{array}{l}\text { Between } \\
\text { Groups }\end{array}$ & 58.132 & 1 & 58.132 & \multirow{2}{*}{32.293} & \multirow{2}{*}{.001} & \multirow{2}{*}{.418} \\
\hline & $\begin{array}{l}\text { Within } \\
\text { Groups }\end{array}$ & 81.01 & 46 & 247.0 & & & \\
\hline \multirow[b]{2}{*}{ Test } & $\begin{array}{l}\text { Between } \\
\text { Groups }\end{array}$ & 249.94 & 1 & 249.94 & \multirow{2}{*}{43.09} & \multirow{2}{*}{0.001} & \multirow{2}{*}{0.49} \\
\hline & $\begin{array}{l}\text { Within } \\
\text { Groups }\end{array}$ & 227.69 & 46 & 5.06 & & & \\
\hline
\end{tabular}

Table (8) shows statistically significant differences among means of both groups' delayed achievement test at the levels of (memorizing, comprehension and application) 


\section{Discussion of Results}

- There are differences among the means of students' scores in the experimental and control groups in the achievement test, in favor of the experimental group; the independent variable (iPad educational applications) affects the dependent variable (achievement). This agrees with the results of Khalifa (2009), Muhammad and Obedat (2010), Al Harby (2010), and Ibrahim (2011) because such applications are based on the educational games. Accordingly, the same results would be given. However, it has various characteristics over the other educational games, mentioned in the theoretical framework. The study is the first, to the author's knowledge, discusses using iPad educational applications in teaching to measure retaining the impact of learning. Carr (2012) discusses using iPad applications that do not find statistically significant differences regarding the impact of iPad educational applications in teaching.

- There are differences among the means of students' scores in the experimental and control groups in the achievement test, in favor of the experimental group; the independent variable (iPad educational applications) affects the dependent variable (scores of achievement). This agrees with Al Harbi (2010) and Al Saedi (2014), proving the effectiveness of educational games in retaining the impact of learning.

- While using iPad, students feel happy and compete each other. The easiness of operating the tablet made it easy for the teacher as it does not take long to run or load the game. This agrees with Schuck et al. (2016), using iPad application to improve child's behavior who suffer from attention and hyperactivity deficit.

- Merging games using iPad educational applications decreases dependency on verbal explanation that causes boredom. This agrees with Falloon \& Khoo (2014), reporting the high levels of tasks accomplishment.

- Using iPad applications based on educational games supports and consolidates learning due to the interaction with the material. This agrees with Anonymous (2010) and Petsche (2011).

- Squire (2005) reports that the only deficit that may happen of using educational games is the time consumed to guide students, and the time consumed in running the game. However, this does not occur because iPad runs via iOS system which is fast.

\section{Conclusion}

In the light of the rapid digital development in the entire world, the teacher must keep pace with the process of teaching and seek to apply the activities in the classroom through utilizing of the latest technologies, whether iPad or otherwise, to address the students in the language of their age. This language is the technology that has emerged in all areas of life. If the teacher disregards this aspect, the students will feel the frustrating learning environment that is far from reality, which is lacking the motivation to learn.

The applications of smart devices, iPad or others, offers a lot of applications and activities that facilitate the task of the teacher. It is is a constantly renewed world where hundreds of thousands of learning applications are added to the stores every day and so the teacher can choose what is appropriate for his teaching methods and students.

\section{Recommendations}

- The following recommendations are made:

- Training teachers on using some iPad educational applications by holding workshops in schools.

- Benefiting from teacher manual prepared by the author on the following iPad applications: TINY TAP, Puzzle Games, and Quiz maker in creating educational games that motivate learners.

- Looking for other iPad applications to create educational games that enhance the motivation and satisfy the needs and attitudes of the learner.

\section{References}

Anonymous. (2010). Education and Teaching; New education and teaching data have been reported by researchers at Ben Gurion University of the Negev. Education Letter, 135 .

Carr, J. M. (2012). Does Math Achievement "h'APP'en" when iPads and Game-Based Learning Are Incorporated into Fifth-Grade Mathematics Instruction? Journal of Information Technology Education: Research, 11, 269-286. https://doi.org/10.1007/s10639-006-9024-2 
Cesarone, B., Elementary, E. C. o., \& Early Childhood Education, C. I. L. (2000). Juegos de videos: Investigacion, puntajes y recomendaciones (Video Games: Research, Ratings and Recommendations). ERIC Digest.

Demirbilek, M. (2010). Investigating Attitudes of Adult Educators towards Educational Mobile Media and Games in Eight European Countries. Journal of Information Technology Education, 9, 235-247.

Dipietro, M., Ferdig, R. E., Boyer, J., \& Black, E. W. (2007). Towards a Framework for Understanding Electronic Educational Gaming. Journal of Educational Multimedia and Hypermedia, 16(3), 225-248.

Fester, V. D. (2012). Catching The Mobile Technology Wave: Can The Ipad Enhance Learning And Teaching In Chemistry? In L. G. Chova, I. C. Torres, \& A. L. Martinez (Eds.), Edulearn12: 4th International Conference on Education and New Learning Technologies (pp. 5712-5721). Valenica: Iated-Int Assoc Technology Education a\& Development.

Flower, A. (2014). The Effect of iPad Use During Independent Practice for Students with Challenging Behavior. Journal of Behavioral Education, 23(4), 435-448. https://doi.org/10.1007/s10864-014-9206-8

Green, S. B., Akey, T. M., Flemming, K. K., Hershberger, S. L., \& Marquis, J. G. (1997). Effect of the number of scale points on chi-square fit indices in confirmatory factor analysis. Structural Equation Modeling, 2, 108-120. https://doi.org/10.1080/10705519709540064

Gros, B. (2007). Digital Games in Education: The Design of Games-Based Learning Environments. Journal of Research on Technology in Education, 40(1), 23-38. https://doi.org/10.1080/15391523.2007.10782494

Hense, J., Mandl, H., \& International Association for Development of the Information, S. (2012). Learning "in" or "with" Games? Quality Criteria for Digital Learning Games from the Perspectives of Learning, Emotion, and Motivation Theory: International Association for Development of the Information Society.

Moreno-Ger, P. et al. (2008) Educational game design for online education, Computers in Human Behavior, https://doi.org/10.1016/j.chb.2008.03.012.

Otsuki, Y., Bandoh, H., Kato, N., Indurkhya, B., \& Nakagawa, M. (2004). Educational Software Employing Group Competition Using an Interactive Electronic Whiteboard. Journal of Interactive Learning Research, 15(3), 257-269.

Petsche, J. (2011). Engage and Excite Students with Educational Games. Knowledge Quest, 40(1), 43-44.

Schuck, S., Emmerson, N., Ziv, H., Collins, P., Arastoo, S., Warschauer, M., . . Lakes, K. (2016). Designing an iPad App to Monitor and Improve Classroom Behavior for Children with ADHD: iSelfControl Feasibility and Pilot Studies. PLoS One, 11(10). https://doi.org/10.1371/journal.pone.0164229

Squire, K. (2005). Game-based learning: Present and future state of the field. Madison, WI: University of Wisconsin-Madison Press.

\section{Arabic References}

Abdulrazeq, E. (2011). Stages and steps of designing and implementing e-training on the internet, retrieved 15, 2, 2014 from http://www.elearning-arab-academy.com/tot/255-2011-08-17-08-19-31.html.

Al Harby, E. M. (2010). Effectiveness of educational games on achievement and retaining the impact of learning in mathematics. Journal of reading and knowledge, 104, 142-168.

Al Nafeai M. (2009). Game's market: High profits. Economics, 9.

Al Noah, M. A. H. (2004). Principles of educational research. Riyadh: Rush Bookstore.

Al Saidi, M. S. (2014). Educational games in teaching mathematics on developing visualization skills and retaining learning impact among the distinguished students with learning difficulties in the intermediate stage, KSA. Journal of mathematics' education, 17(2), 62-112.

Al Shahroura, M., \& Al Remawy, M. A. (2011). Impact of games on recalling, problem-solving, and decision-making among the students of the intermediate stage in Jordan. Educational sciences studies, 38, 637-649.

Attia, M.A. (2008). Communication technology in effective education. Amman: Dar Al Manahej.

Bahi, M. H., \& Elnemr, F. Z. (2004). Evaluation in the field of educational and psychological sciences: Principles, theories, and applications. Cairo: The Anglo Egyptian Bookshop.

Educational Games (n.d.). http://www.elearning-arab-academy.com/edu-games.html. Retrieved on May 6, 2014 from 
Arab eLearning Academy.

Elawn, I. S. H. (2012). Impact of computerized educational games on developing imagination skills among kindergarten students of North Badiya, Jordan. Educational sciences studies, 39 (1), 61-70.

Ellaqany, A. H., \& Eljamal, A.A. (2013). Dictionary of educational terms defined in curricula and methods of teaching. Cairo: Alam Al-kotob.

Khalifa, A. K. (2009). Effectiveness of educational computer games in decreasing attention deficit- attention deficit hyperactivity among primary school students. Proceedings of the fourth Arab scientific conference- $1^{\text {st }}$ international conference, Faculty of Specific Education (Academic accreditation for higher education's institutions and programs in Egypt and the Arab World- Present and future), 4, 2546.

Zahran, H. H., \& Ahmed, M. J. (2010). Effectiveness of computer educational games in developing visual-spatial visualization skills of maps and attitudes among preparatory school students. Studies in curricula and methods of teaching, 158, 58-112.

\section{Appendices}

\section{Appendix (1)}

Teaching Manual of the Sixth Unit (Resources of my Country) Using Educational Games-Based iPad applications

\section{Introduction}

Using technology is one of the most significant modern methods which draw the learners' attention and provide them interaction and participation strategy rather than receiving the information. Educational games, which involve effective educational materials and purposeful educational activities, obviously achieve such positive role. Traditional educational games, such as cards and wood assembling games, and educational games with their different devices and programs paly a similar role. Due to the current technological evolution and the prevalence of desktops, laptops, devices of various games, such as PlayStation, Xbox, GameBoy and Wii; tablets, such as Galaxy Tab, iPad and iPod; and smart phones, such as iPhone, BlackBerry and Galaxy, games have become prevalent among the adults and the young. Accordingly, games should be used in education according to the educational objectives.

\section{Educational Objectives}

The student is expected to be able to:

- Identify the economic and natural resources in KSA.

- Realize the significance of natural resources.

- Identify the characteristics of the Governorate's population, resources and how to reduce consumptions.

- Identify the population's activity in KSA. 
Time Plan of the Experiment Application

\begin{tabular}{|c|c|c|c|c|}
\hline \multicolumn{5}{|c|}{ Pre-Test 19/1/2016 } \\
\hline Title & $\begin{array}{c}\text { Experimental } \\
\text { Group }\end{array}$ & $\begin{array}{l}\text { Control } \\
\text { Group }\end{array}$ & Class Date & $\begin{array}{l}\text { No. of } \\
\text { classes }\end{array}$ \\
\hline $\begin{array}{c}\text { Resources of } \\
\text { Water }\end{array}$ & \multirow{5}{*}{ 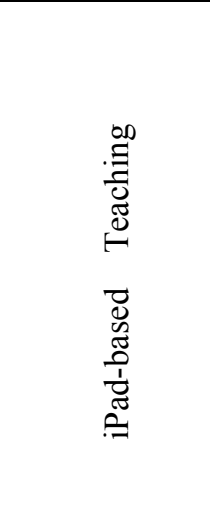 } & \multirow{5}{*}{ 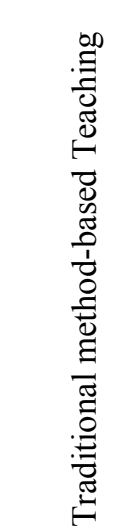 } & $25 / 1 / 2016$ & 1 \\
\hline Natural Plant & & & $27 / 1 / 2016$ & 1 \\
\hline Animal Resources & & & $1 / 2 / 2016$ & 1 \\
\hline Oil and Minerals & & & $3 / 2 / 2016$ & 1 \\
\hline $\begin{array}{c}\text { Population's } \\
\text { Activity }\end{array}$ & & & $15-17 / 2 / 2016$ & 1 \\
\hline \multicolumn{5}{|c|}{ Post-Test 22/2/2016 } \\
\hline \multicolumn{5}{|c|}{ Delayed Test 4/4/2016 } \\
\hline
\end{tabular}

\section{Behavioral Procedural Objectives}

\begin{tabular}{|l|l|}
\hline Title & \multicolumn{1}{|c|}{ Objective } \\
& $\begin{array}{l}\text { The student is expected to : } \\
\text { 1. Define surface water in KSA. } \\
\text { 2. Define underground water in KSA. } \\
\text { 3. Deduce desalination. } \\
\text { 4. Explain the reasons for desalination in KSA. } \\
\text { 5. Explain the significance of water on the surface of the } \\
\text { ground. } \\
\text { 6. Define some waterbody types } \\
\text { on the map. } \\
\text { 7. Deduce three resources of water in the Arabian } \\
\text { Peninsula. } \\
\text { 8. Create a map of water resources in the Arabian } \\
\text { Peninsula. } \\
\text { 9. Compare between surface water and underground water. } \\
\text { 10. Expect the future of water in the Arabian Peninsula } \\
\text { according to rains amount. } \\
\text { 11- State the reasons for water scarcity in the Arabian } \\
\text { Peninsula }\end{array}$ \\
\end{tabular}




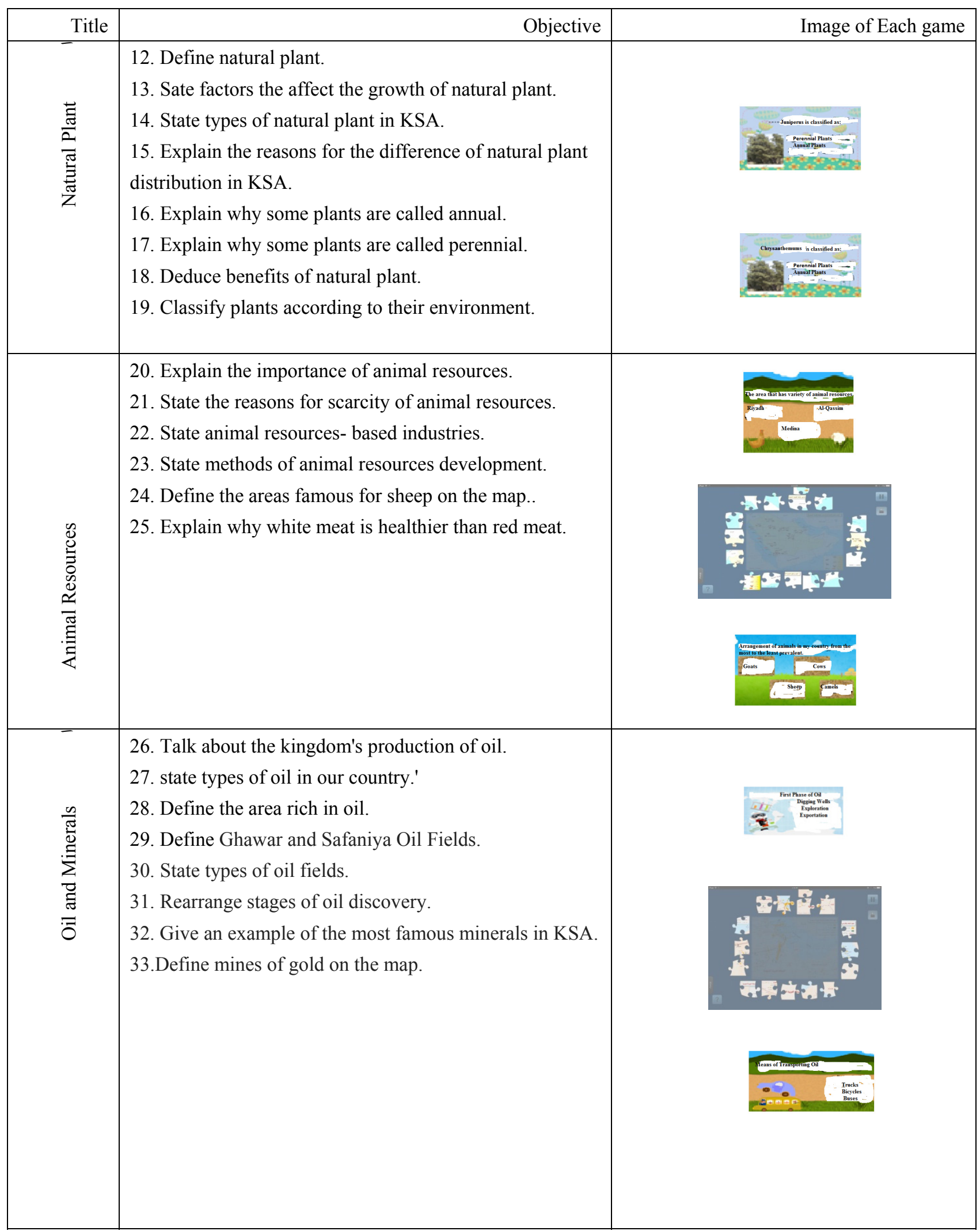




\begin{tabular}{|c|c|c|}
\hline Title & Objective & Image of Each game \\
\hline 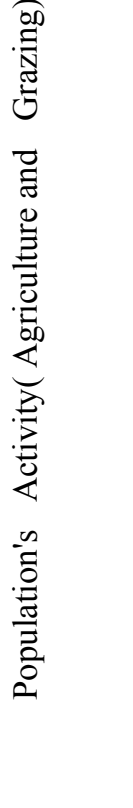 & $\begin{array}{l}\text { 34. Define population's Activity. } \\
\text { 35. State Population's Activities. } \\
\text { 36. Define the relation between population's activity and } \\
\text { the environment. } \\
\text { 37. Talk about agriculture and its significance for the } \\
\text { community. } \\
\text { 38. State some agricultural products in KSA. } \\
\text { 39. Explain why the south eastern provinces in KSA have } \\
\text { no agriculture. } \\
\text { 40. Explain the reasons for grazing deterioration. } \\
\text { 41. Deduce the role and significance of agriculture in the } \\
\text { community. } \\
\text { 42. State methods of grazing in KSA. } \\
\text { 43. Explain the reasons for deterioration of natural } \\
\text { pastures. }\end{array}$ & 隹 \\
\hline 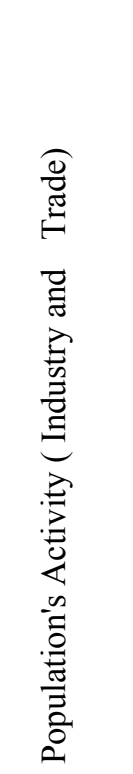 & $\begin{array}{l}\text { 44. Define industry. } \\
\text { 45. State benefits of industry. } \\
\text { 46. State the most significant industries in KSA. } \\
\text { 47. Explain the reasons for establishing Jubail and Yanbu } \\
\text { industrial cities away from populated areas. } \\
\text { 48. Count industrial cities in KSA. } \\
\text { 49. Deduce the reason for the prevalence of industrial cities } \\
\text { in most areas in KSA. } \\
\text { 50. Sate benefits of industry. } \\
\text { 51.State fundamentals of industry. } \\
\text { 52. State divisions of industry. } \\
\text { 53. Sate types of Trade in KSA. } \\
\text { 54. Compare between exports and imports. } \\
\text { 55.Define Services. }\end{array}$ & 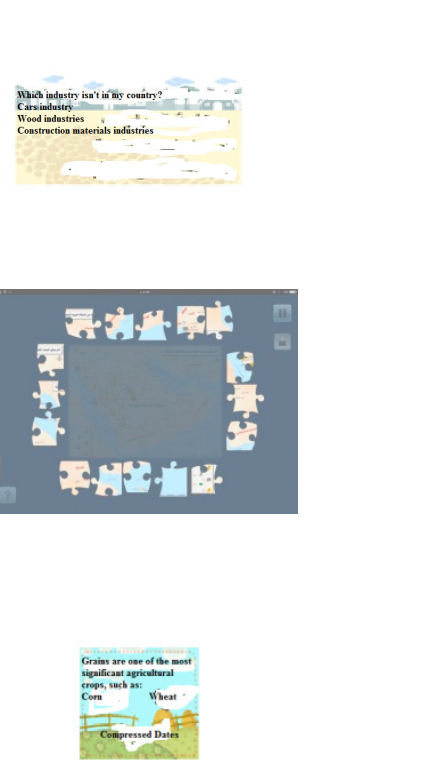 \\
\hline
\end{tabular}

\section{Strategies of Teaching}

Recitation, discussion, brainstorming, and educational games-based iPad applications

\section{Assessment}

- Constructive assessment: asking questions while explaining and presenting the lesson through the discussion and providing feedback during the class.

- Final Assessment: Quiz maker application was used.

Images of quiz maker application, which were used in assessment stage, are as follows: 


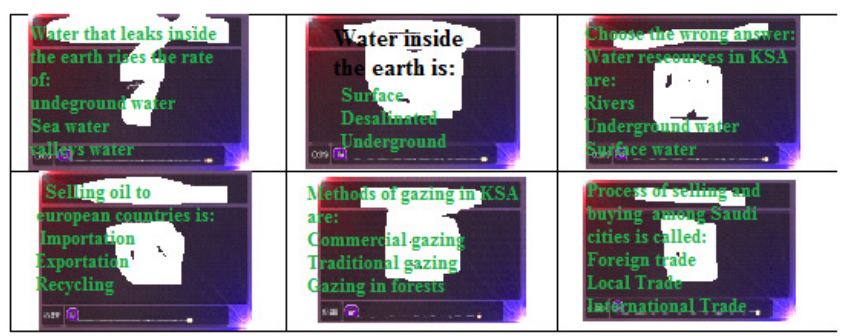

Appendix (2)

Reviewers

\begin{tabular}{|c|c|c|}
\hline Reviewer & Affiliation & $\begin{array}{c}\text { Degree and Area of } \\
\text { Specialization }\end{array}$ \\
\hline Prof. Sausan Mohamed Ezz Eldeen & $\begin{array}{c}\text { Faculty of Education, King Abdulaziz } \\
\text { University }\end{array}$ & $\begin{array}{c}\text { Professor of curricula and } \\
\text { teaching methods of } \\
\text { mathematics }\end{array}$ \\
\hline Dr. Habba Ahmed Akram & Faculty of Education, King Abdulaziz \\
University & $\begin{array}{c}\text { Assistant Professor of } \\
\text { curricula and teaching } \\
\text { methods of Sharia sciences }\end{array}$ \\
\hline Dr. Abdelraheem Ibn Newagea Al Harby & $\begin{array}{c}\text { Supervisor of Planning and Development, } \\
\text { Directorate of Education, Yanbu. } \\
\text { Teaching staff member (Part-timer)at the } \\
\text { University College in Amlaj, University of } \\
\text { Tabuk. }\end{array}$ & $\begin{array}{c}\text { Ph.D. in curricula and } \\
\text { teaching methods of social } \\
\text { studies }\end{array}$ \\
\hline Miss. Faiza Al Gahdly & Primary, 131 & Teacher \\
\hline Miss. Houda Al Zahrany & Primary, 161 & Teacher \\
\hline
\end{tabular}

Appendix (3)

Final Form of Achievement Test

Achievement Test on the sixth Unit (Resources of my Country)

Name:

Class:

\section{Dear student,}

Read the instructions, then answer the questions:

1. Time is 30 minutes.

2. Number of questions is 20 and total mark is 20 .

3 . Number of pages is 3 , including cover page.

4. Read the question carefully before selecting the correct answer.

5. Don't skip any question.

6. You have to answer in the questions sheet. 
Answer the following questions

\section{Explain the reasons}

1. My country is one of the countries that lack water.

2. Variety of plant resources in my country.

3. Scarcity of animal resources in my country.

4. Reduction of farmers in the recent years.

5. Deterioration of grazing trade at the present.

6. Establishing Jubail and Yanbu industrial cities away from the populated areas

\section{Choose the correct answer}

7. Water, which leaks inside the earth, raises the rate of: $\square$ sea water $\square$ valleys water $\square$ underground water

8. Calligonum grows in: $\square$ valleys $\square$ sand $\square$ mountains

9. Keeping cows is prevalent in: $\square$ Aseer $\square$ Jazan $\square$ Riyadh

10.Which provinces involve most of oil fields: $\square$ The Eastern $\quad \square$ The Northern $\square$ The Western

11. The largest oil field, that produces the most on land, is: $\quad \square$ Saffaniyah $\quad \square$ Ghawar $\square$ Manifa

12. Animal resources, in KSA, is substantially based on: $\square$ Sheep

$\square$ Cows $\quad \square$ Camels

13. The main exports in KSA are: $\quad \square$ Oil $\quad \square$ Fruits $\quad \square$ Cars

III. Tick ( $\sqrt{ })$ or $(\mathrm{X})$ :

14. Animal type, in my country, differs according to the environment where it grows. ( )

15. Desalination means to keep water in large tubes and add sugar. ( )

16. Availability of raw materials is one of the main fundamentals of industry. ( )

\section{Fill in the following mind maps:}

17

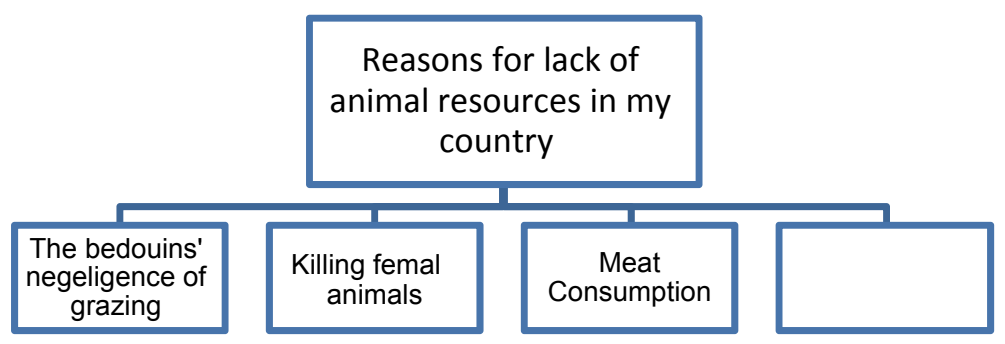

18

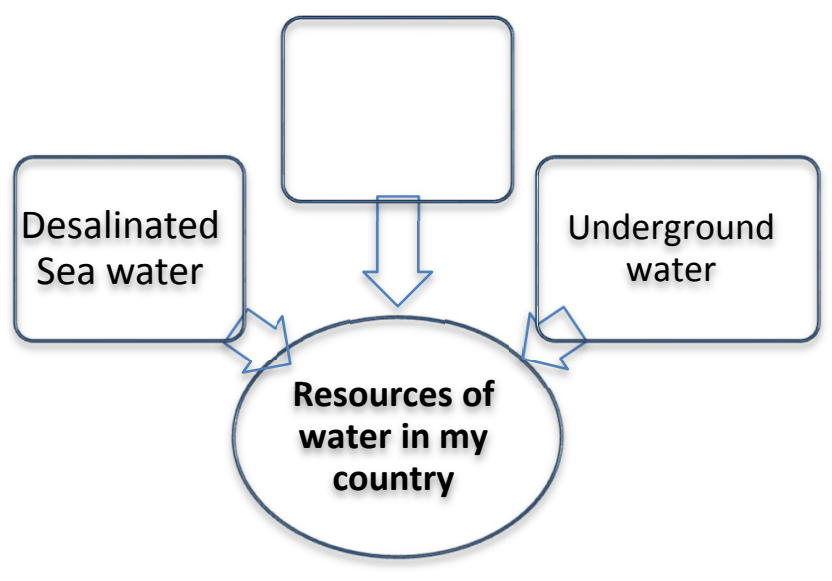


V. Distribute oil and mineral resources on the following map of KSA fields of using its symbols:

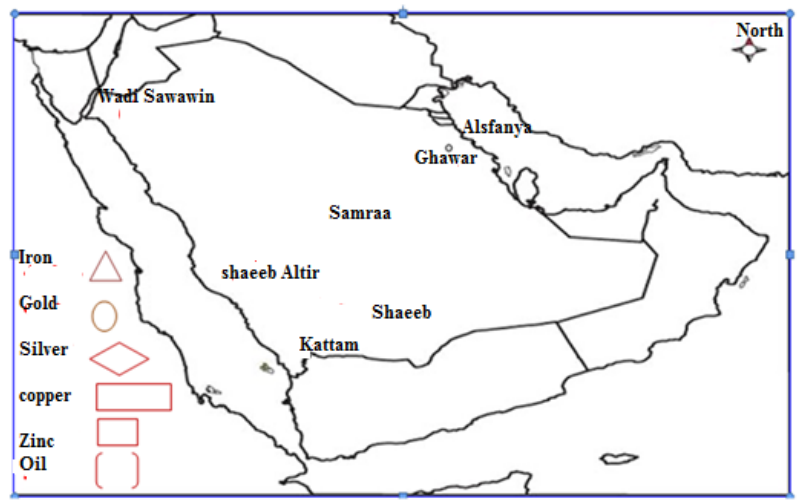

VI. According to the map, how many agricultural cities are there in KSA?

Number of agricultural cities is.............................

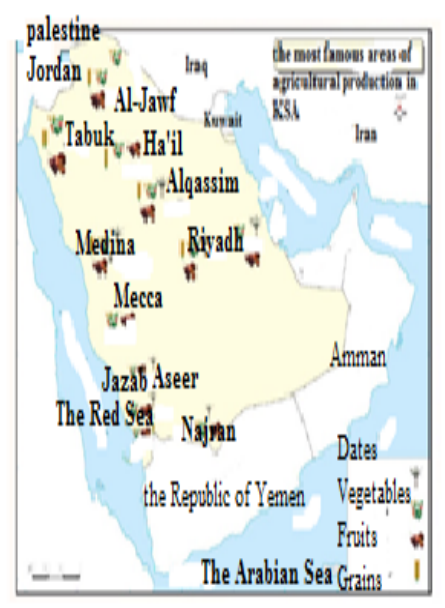

